\title{
ANALYSIS OF HABITAT CHANGES OF CASPIAN RED DEER (CERVUS ELAPHUS MARAL GRAY, 1850) BASED ON TEMPORAL CHANGES OF EFFECTIVE AREA AND FUNCTIONAL CONNECTIVITY - A CASE STUDY OF LISAR PROTECTED AREA
}

\author{
PANAHANDEH, M. ${ }^{*}-$ YAVARI, A. R. ${ }^{2}-$ SAlEhI, E. ${ }^{3}-$ MALEKMOHAMMADI, B. ${ }^{4}$ \\ ${ }^{I}$ Department of Environmental Planning and Management, Graduate Faculty of Environment, \\ University of Tehran, Tehran, Iran \\ (phone: +98-930-979-3288) \\ ${ }^{2}$ Department of Environmental Planning and Management, Graduate Faculty of Environment, \\ University of Tehran, Tehran, Iran \\ (phone: +98-912-390-7922; email: ayavari@ut.ac.ir) \\ ${ }^{3}$ Department of Environmental Planning and Management, Graduate Faculty of Environment, \\ University of Tehran, Tehran, Iran \\ (phone: +98-912-375-2788; email: tehranssaleh@ut.ac.ir) \\ ${ }^{4}$ Department of Environmental Planning and Management, Graduate Faculty of Environment, \\ University of Tehran, Tehran, Iran \\ (phone: +98-912-338-6360; email: malekb@ut.ac.ir) \\ *Corresponding author \\ e-mail:m1344_panahandeh@yahoo.com \\ (Received 22 ${ }^{\text {nd }}$ Apr 2016; accepted $16^{\text {th }}$ Jun 2016)
}

\begin{abstract}
A growing number of human activities are among the top factors causing habitat loss and fragmentation. The aim of this study was to investigate the temporal changes in habitat suitability, connectivity status and analysis of these changes using landscape ecology approach. Evidences indicate high probability of local extinction of Caspian red deer (Cervus elaphus maral Gray, 1850) in the current habitats of Guilan province in the north of Iran due to severe habitat destruction. In this study, habitat suitability layers and corridors were drawn with combining layers of land cover derived from the interpretation of satellite images, elevation, topography and distance to man-made in the period 19902015. Accordingly, 35\% decrease in area metric of habitat suitability, $34 \%$ increase in the number of patches, $89 \%$ in edge density and 53\% reduction in the average size of patches indicate that the occurrence of habitat fragmentation along with habitat loss, severely disrupted the integrity of the habitat. As a result, in all corridors, the relative share of semi-dense and dense forest cover were reduced. Research results have given a clear picture of the extent of changes in habitat suitability and connectivity paths that can have an effective role in restoration process.
\end{abstract}

Keywords: landscape ecology, fragmentation, habitat loss, suitability, biodiversity, corridors

\section{Introduction}

Currently, in most regions of the world, there is an unprecedented increase in the destruction of natural habitats (Ellis et al., 2010). In the last 50 years, human activities have grown faster and wider than in any other period in history, have altered the ecosystem; and more than $60 \%$ of global ecosystems have been destroyed during this time (Lopoukhine et al., 2012). Habitat loss has negative consequences on species richness (Laurance et al., 2002) and genetic diversity (Aguilar et al., 2008). Moreover, 
habitat loss can shorten the length of a food chain, change species interaction, and reduce levels of nutrition, breeding and dispersion (Fahrig, 2003). Habitat loss not only affects biodiversity, but also has direct consequences on humans by reducing resources and ecosystem services such as pollination (Potts et al., 2010; Ricketts et al., 2008), as well as soil and water management (Bruijnzeel et al., 2004). In a study, after calculating the potential economic benefits of habitat loss, according to a conservative estimate, the final economic cost of habitat destruction was estimated at $\$ 250$ billion per year (Balmford et al., 2002).

Habitat fragmentation is the second major impact of human activities in which habitat is divided into smaller pieces (Ewers et al., 2006; Andren, 1994). During the twentieth century, human activities with changes in land use and habitat fragmentation, in addition to reducing the effective area of habitat, have affected the status of connectivity within and between habitats and have created serious threats to biodiversity worldwide. With destruction and fragmentation of landscape, their connectivity status is more discrete with negative impact on biodiversity. As populations and communities become more isolated, the possibility of dispersion and movement between habitats reduces. According to the metapopulation theory, the reducing potential of dispersion reduces the opportunity of the native endangered species to recolonize (Hanski, 2010), thereby resulting in large scale destruction of biodiversity.

In the long term, a decrease in connectivity has negative effects on population viability by reducing the genetic diversity (Lienert, 2004). The loss of connectivity on landscape scale also has negative consequences at the regional and international levels; this is because connectivity is an important prerequisite for species to move over long distances in order to avoid extinction due to climate change (Krosby et al., 2010). Connectivity is the key factor to understand how ecological systems respond to the challenges of land use change, habitat loss and fragmentation (Auffret et al., 2015). Connectivity means show that the surroundings facilitate or impede the movement of organisms and ecological units (Taylor et al., 1993; Zeller et al., 2012; Trainor et al., 2013; Pflüger and Balkenhol., 2014). It has two structural and functional components. Structural connectivity is the potential physical property of a land or habitat that allows the movement of organisms and ecological units, while functional connectivity is the actual conditions of a land or habitat that allows movement of living things and ecological units (Fischer and Lindenmayer, 2007).

In the face of increasing habitat destruction, strengthening and expanding protected areas is one of the important strategies in biodiversity protection (Waldhart, 2003; Andelmand et al., 2003). Protected areas are natural areas officially protected within the administrative boundaries due to the presence of natural specific properties. Wiens (2009) presented the concept of the effective area of the protected areas and this area does not necessarily coincide with the administrative boundaries, but can be more limited or go beyond administrative boundaries.

Therefore, the aim of this study was to investigate the temporal changes in habitat suitability as the basis of the effective area of protected areas, their connectivity status over time and analysis of these changes using metrics of landscape ecology. In this research, Lisar protected area in Guilan province in the north of Iran was chosen and the target species was Caspian red deer (Cervus elaphus maral Gray, 1850). Caspian red deer is the largest native deer in Iran and in recent years, its habitat has been severely degraded in the north of Iran (Kiabi et al., 2004). Evidences indicate high probability of 
local extinction of Caspian red deer in the current habitats of Guilan province in the north of Iran due to severe habitat destruction.

Similar to the present research conducted in Iran, previous studies have been conducted on the "Impact assessment of changes in land use and vegetation on habitat of Caspian red deer in Gorgan and Kordkoi region" (Parvian, 2012). In this study, 8 environmental variables, as independent parameters, were used to map the suitability habitat. The results of this study showed that the variable of distance to man-made is the most important. In a study on the "Determination of protection class of Caspian red deer under the conditions of uncertainty in the north of Iran" (Gholipour, 2012), 9 criteria were used to assess the habitat of Caspian red deeer. According to this survey, more than $75 \%$ of the habitat of Caspian red deer has been destroyed. Also, Kiabi et al. (2004), in their study on "Population status, biology and ecology of Caspian red deer (Cervus elaphus maral Gray, 1850) in Golestan National Park, Iran", examined the demographic characteristics and spatial distribution of Caspian red deer.

This study can be distinguished from others based on the use of analysis of temporal changes of the habitat suitability layer as the basis of the effective area of protected areas and the analysis of temporal changes of connectivity. Also, in this study, landscape ecology metrics were used in levels of habitat suitability and corridors.

\section{Materials and Methods}

\section{Materials}

Study area

Lisar protected area, with an area of 32000 ha, is located in the west of Guilan province in the north of Iran with geographical coordinates of $48^{\circ} 32^{\prime} 35^{\prime \prime}$ to $48^{\circ} 56^{\prime} 24^{\prime \prime}$ east longitude and $37^{\circ} 53^{\prime} 06^{\prime \prime}$ to $38^{\circ} 02^{\prime} 10^{\prime \prime}$ north latitude (Fig. I).

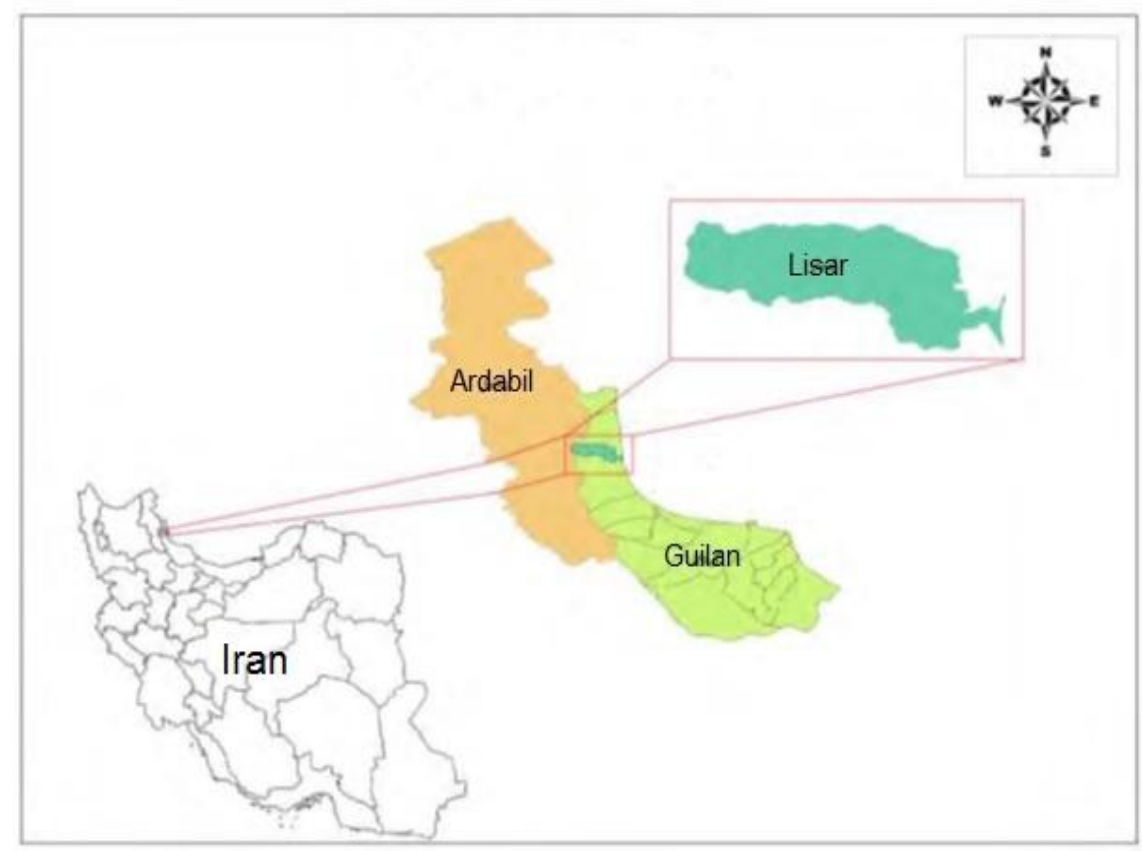

Figure 1. Location of Lisar protected area in the province of Gilan. 
According to Köppen climate classification system, Lisar has Mediterranean climate (Csa). The average annual precipitation is $1224 \mathrm{~mm}$ and the average annual temperature is $15.5^{\circ} \mathrm{C}$ (Table 1). (Guilan Department of Environment- Climate and Weather, 2005).

Table 1. Precipitation and temperature condition.

\begin{tabular}{lllllllllllll}
\hline Month & $\mathbf{1}$ & $\mathbf{2}$ & $\mathbf{3}$ & $\mathbf{4}$ & $\mathbf{5}$ & $\mathbf{6}$ & $\mathbf{7}$ & $\mathbf{8}$ & $\mathbf{9}$ & $\mathbf{1 0}$ & $\mathbf{1 1}$ & $\mathbf{1 2}$ \\
\hline $\mathbf{m m}$ & 102 & 94 & 95 & 63 & 41 & 31 & 29 & 79 & 181 & 230 & 163 & 116 \\
\hline${ }^{\circ} \mathbf{C}($ Mean $)$ & 6 & 6.1 & 8.3 & 13.1 & 18.5 & 23.0 & 25.6 & 25.5 & 22.2 & 17.4 & 1.2 & 8.4 \\
\hline${ }^{\circ} \mathbf{C}(\min )$ & 2.8 & 2.9 & 5.1 & 9.5 & 14.5 & 18.6 & 20.9 & 20.6 & 18.1 & 13.6 & 8.6 & 4.8 \\
\hline${ }^{\circ} \mathbf{C}(\max )$ & 9.2 & 9.3 & 11.5 & 16.8 & 22.6 & 27.4 & 30.4 & 30.5 & 26.3 & 21.3 & 15.9 & 12.0 \\
\hline
\end{tabular}

Elevation ranges between -100 to 3400 meters. The study area is located in Alborz zone, subzone of Central- West Alborz zone in Gorgan - Rasht unit. Based on stratigraphy, geological formations and rocks of studied area belong to the Precambrian and Quaternary. Main families of soil are sandy mixed (nonacid) mesic, fine loamy mixed (nonacid) mesic, clay mixed (nonacid) mesic, loamy skeletal mixed (calcareous) mesic, sandy skeletal (nonacid) mesic, loamy (nonacid) mesic. (Guilan Department of Environment - Geology and Geomorphology, 2005).

Main forest types in the region are: Carpinus betulus- Parrotia persica, Parrotia persica- Carpinus betulus, Quercus castaneifolia- Carpinus betulus, Fagus orientalis, Fagus orientalis- Carpinus betulus, Fagus orientalis-Carpinus betulusAcer velutinum, Quercus castaneifolia, Carpinus betulus-Parrotia persica- Quercus castaneifolia, Quercus castaneifolia-Parrotia persica-Carpinus betulus, Carpinus betulus- Tilia begonifolia- Acer velutinum, Parrotia persica-Carpinus betulusDiospirus lotos, Carpinus betulus- Diospirus lotos, Quercus castaneifolia- Tilia begonifolia- Carpinus betulus, Parrotia persica- Carpinus betulus- Gleditchia caspica.

Main pasture types in the region are: Festuca-Trifolium, Astragalus- Poa, Astragalus- Acanthlimon, Trifolium - Festuca, Festuca - Dactylis -Trifolium, Festuca-Trifolium- Dactylis, Festuca -Trifolium -Agropyron, Festuca -TrifoliumAstragalus, Astragalus- Festuca- Acantholimon, Festuca- Trifolium -Hordeum, Astragalus- Agropyron, Festuca- Hordeum, Festuca- Astragalus, FestucaAstragalus- Poa,Festuca-Agropyron-Astragalus, Astragalus- Festuca- Agropyron .

Main typical agricultural plants of the region are: rice, cherry and kiwifruit(Guilan Department of Environment - Vegetation, 2005).

There are 40 animal mamal species from 27 families in the region. The main families are: Cervidae, Suidae, Felidae, Canidae and Ursidae(Guilan Department of Environment - Wildlife, 2005).

The diversity of deciduous forest species provide good food sources for Caspian red deer. Although, Caspian red deer is widely distributed in this region, but numerous access roads and in recent years, access to the country side with increased ease of access to the forest and pristine habitats have resulted in security challenges and increase in poaching. 


\section{Methods}

In this study, in order to analyze temporal changes in the habitat of Caspian red deer, the habitat suitability layer was built based on layers of land cover and land use, topography, elevation, and distance to man-made centers (Beier et al., 2009). In this regard, landsat satellite images of 1990-2015, used for the identification and extraction of land cover and land use, were interpreted as follows:

- Low dense forest cover (Canopy cover less than 40\%).

- Semi-dense forest cover (Canopy cover 40-70\%)

- Dense forest cover (Canopy cover more than 70\%)

- Pasture

- Agriculture

- bare

- Man-made

The supervised classification method was used, and training samples needed in 1990 were obtained from aerial photos and in the year 2015 from reference maps and field study. Elevation and topographic layer were derived from DEM maps of the area. Expert opinion and hierarchical analysis methods were used to obtain the value (0-100) of the weighting parameters and classes (Zeller et al., 2012; Trainor et al., 2013; Pflüger and Balkenhol., 2014). The habitat suitability layer for the period 1990-2015 was produced using Corridor DesignerToolbox_v0.2 (Majka et al., 2007) and their changes were analyzed based on landscape metrics using the Patch analyst extension (Rempel et al., 2012).

In order to present the situation of connectivity and compare both periods, four blocks on habitat suitability layer in 1990, as a base year, were created in different parts of the habitat suitability layer (Sawyer et al., 2011) and 6 corridors were drawn separately based on a maximum of 6 possible combinations of the four blocks during the period 1990-2015, and their temporal changes were analyzed based on landscape metrics using the Patch analyst extension. The distribution of blocks and corridors is a measure of the connectivity status of the study area. The cost-least corridor method was used to draw the corridors (Beier et al., 2009).

\section{Result and Discussion}

By combining the layers of land use and land cover during the period 1990-2015, based on the scores and weights defined for each layer and class, habitat suitability layer with a score of 50 and above was prepared during this period (Fig.2 and Fig.3).

Based on the four defined blocks, 6 corridors between them was drawn on the habitat suitability layer during the period 1990-2015(Fig.4 and Fig.5). The images of land use and land cover show the displacement of corridors on the habitat suitability layer in the period 1990 (as the base year) (Fig.6). 


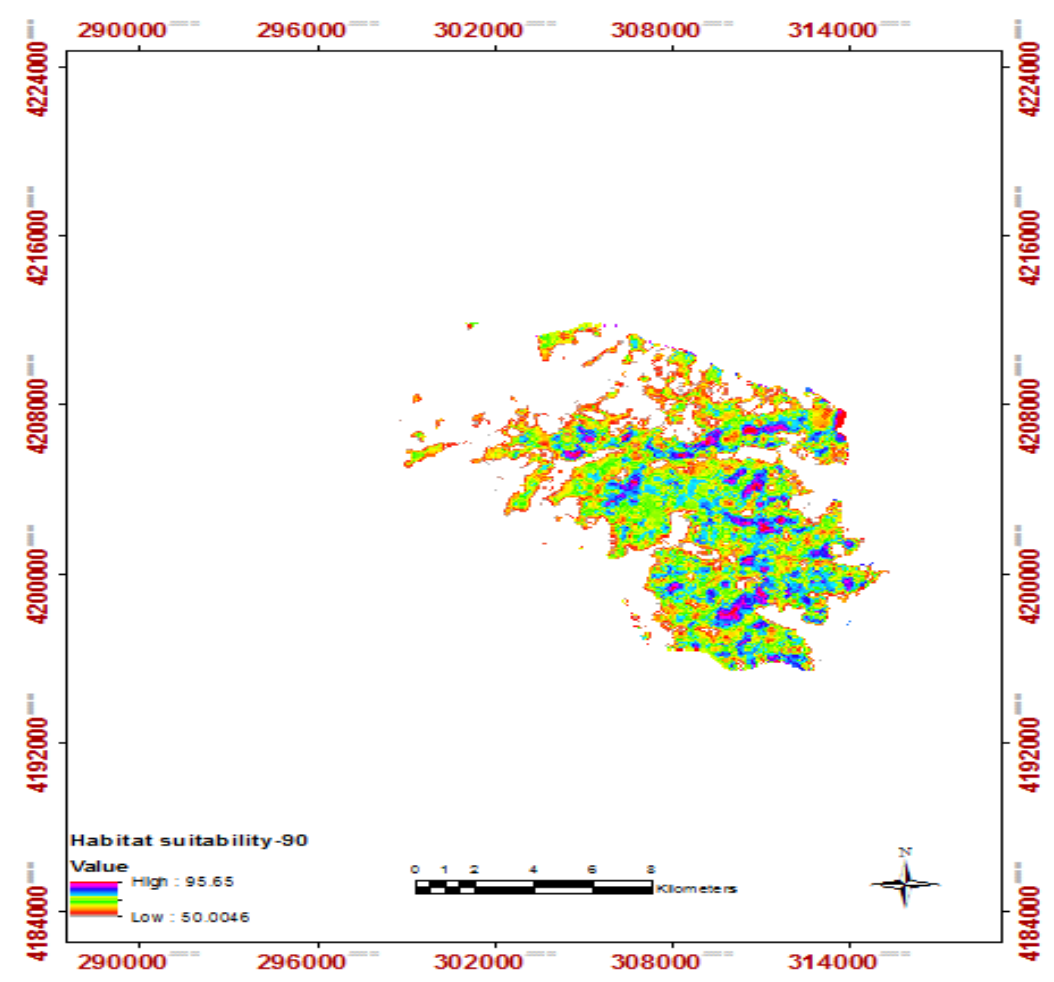

Figure 2. Habitat suitability in 1990.

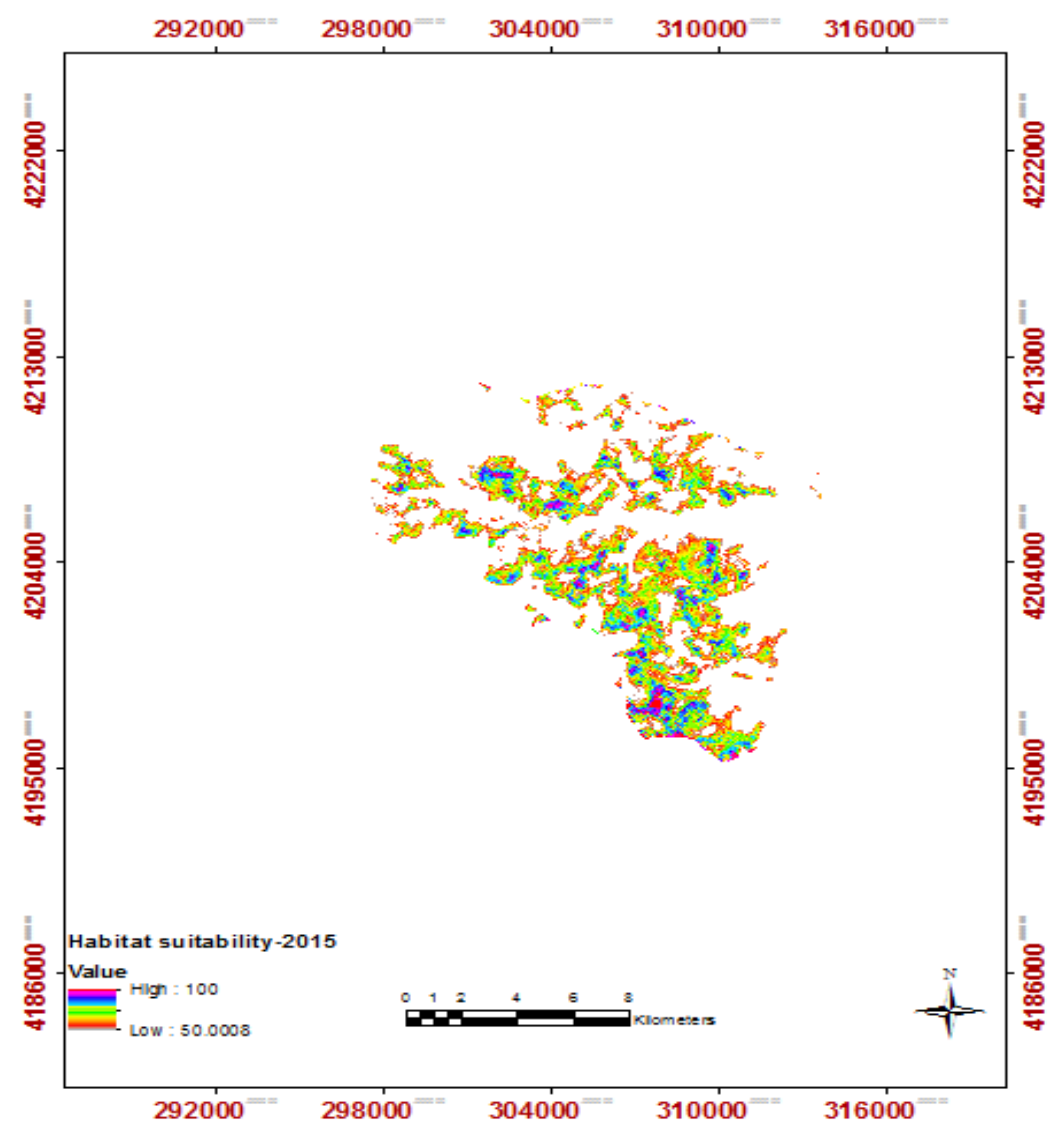

Figure 3. Habitat suitability in 2015. 


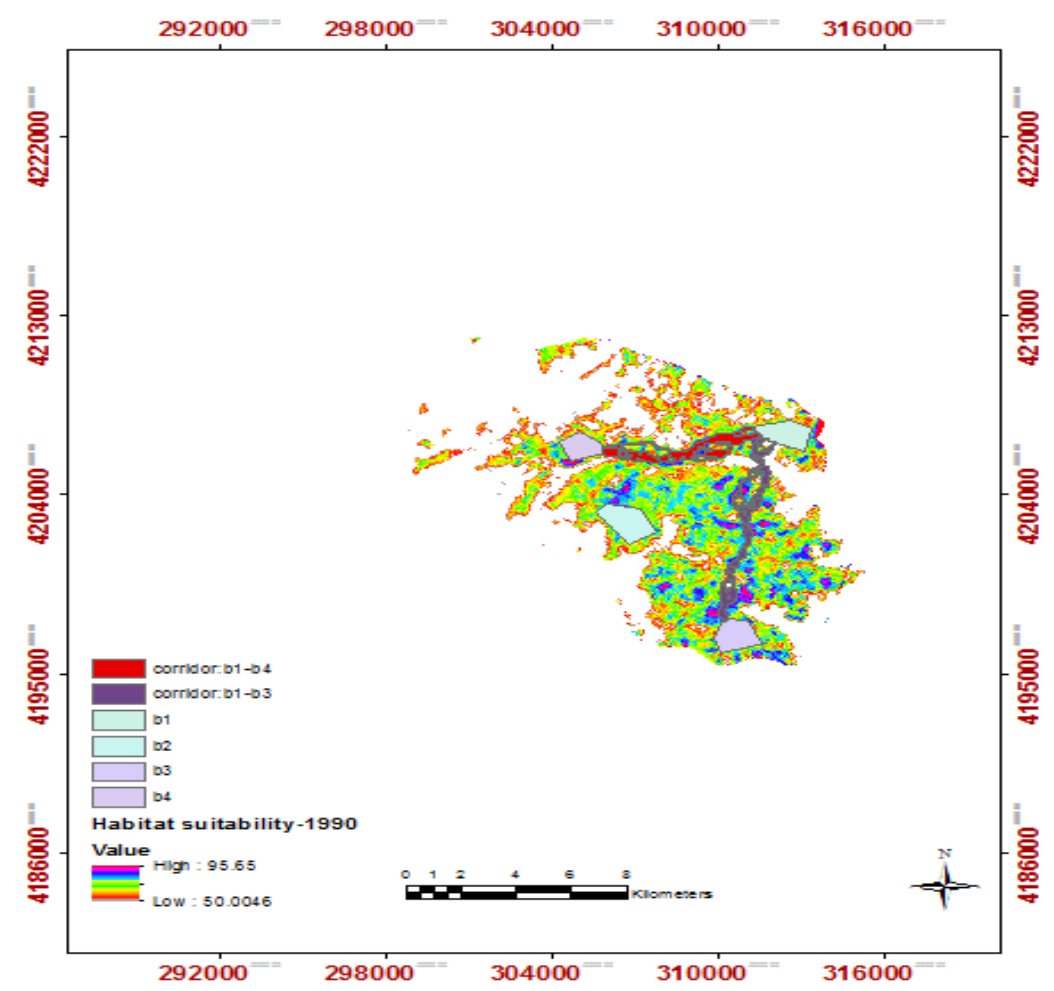

Figure 4. Corridors on habitat suitability layer in 1990.

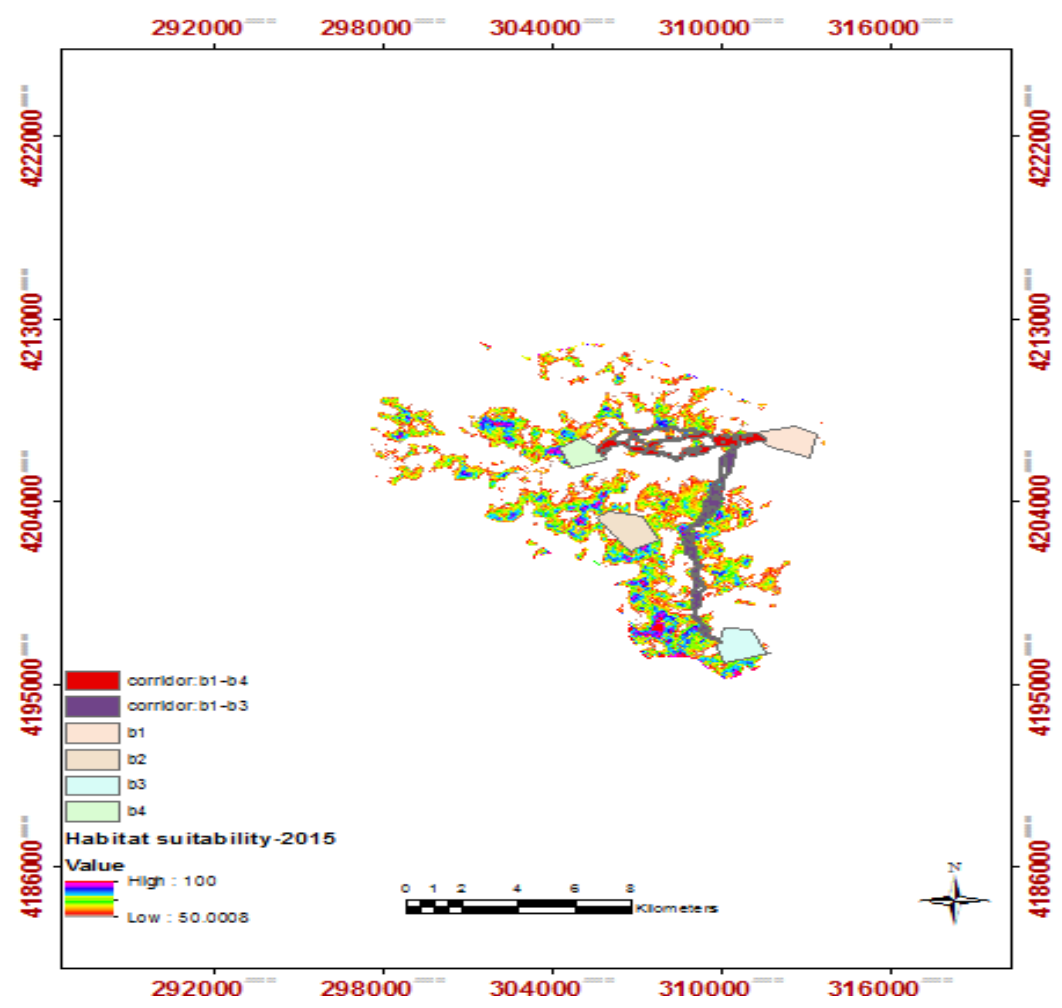

Figure 5. Corridors on habitat suitability layer in 2015. 


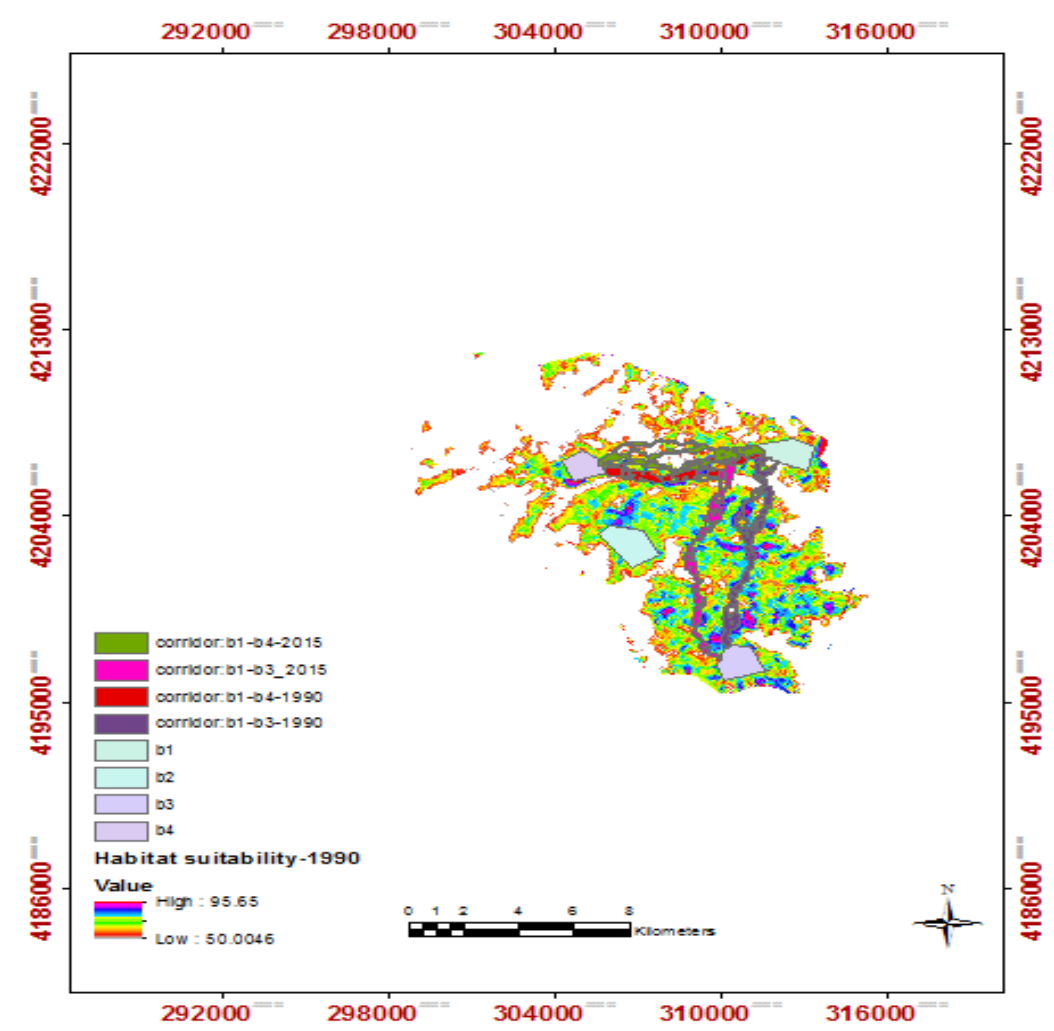

Figure 6. Habitat corridors during the period 1990 to 2015 on habitat suitability layer in 1990.

During the twentieth century, human activities with changes in land use and habitat fragmentation, in addition to decreasing the effective area of habitat, have affected the connectivity within and between habitats and created serious threats to biodiversity worldwide. With destruction and fragmentation of the landscape, their connectivity status is more discrete that have negative impact on biodiversity. As populations and communities become more isolated, the possibility of dispersion and movement between the habitats reduces. Together with the current trend of habitat destruction around the world, analysis of temporal changes of Caspian red deer habitat suitability represents the simultaneous occurrence of severe habitat loss and fragmentation of Lisar protected area. The decrease in area metric of habitat suitability layer to 3444 ha $(35 \%)$ during this period indicates widespread habitat loss in this region (Table2).

Table 2. Comparison of metrics habitat suitability layer during the period 1990-2015.

\begin{tabular}{ccccc}
\hline Metrics & $\mathbf{1 9 9 0}$ & $\mathbf{2 0 1 5}$ & Changes & Change\% \\
\hline Area (ha) & 9837 & 6393 & -3444 & 35 \\
\hline $\begin{array}{c}\text { Number of } \\
\text { patches }\end{array}$ & 129 & 173 & 44 & 34 \\
\hline $\begin{array}{c}\text { Mean of } \\
\text { patches (ha) }\end{array}$ & 76 & 36 & -40 & 53 \\
\hline $\begin{array}{c}\text { Edge density } \\
\text { (m/ha) }\end{array}$ & 28 & 53 & 25 & 89 \\
\hline Total edge (m) & 271837 & 341776 & 69939 & 26 \\
\hline
\end{tabular}


In addition, 34\% increase in the number of patches, $89 \%$ increase in edge density, $89 \%$ increase in total edge and 53\% reduction in the average size of patches indicate that the occurrence of habitat fragmentation along with habitat loss, severely disrupted the integrity of Caspian red deer habitat. These results confirm the findings of Golipor et al. (2012) who reported a 75\% reduction of Caspian red deer habitat in the north of Iran. These results are also in line with the findings of Zebardast et al. (2011), who reported that habitat loss and fragmentation are the most important factors threatening habitat integrity of protected areas. This process could reduce the potential release of Caspian red deer in the Lisar protected area. According to the metapopulation theory, the reducing potential of dispersion reduces the opportunity for native endangered species to recolonize, resulting in the large scale destruction of biodiversity (Hanski, 2011).

These evidences are in line with the report of environmental guards regarding the observed and recorded trend of concerned species and the possibility of local extinction. This result is also in line with the findings of Kiabi et al. (2004) who reported that habitat degradation is a major threat to Caspian red deer. The maps of land use changes show that the destruction of forests and development of human activities are the most important factors of habitat degradation in this study's region. In this regard, dense forest cover decreased from 5606 to 2703 ha and semi-dense forest cover decreased from 4462 to 4262 ha and the area affected by man (man-made) increased from 2364 to 2904 ha. The spatial distribution of changes, in addition to its quantity, caused an increase in edge effect, and a reduction of average patches reduced the habitat integrity. These results are in agreement with the findings of several researches (Farigh, 2003; Ewers et al., 2006; Andren, 1994) in which human activities were reported to be the major cause of habitat degradation through habitat loss and fragmentation. Connectivity analysis within the protected area showed the displacement of corridors, fragmentation and inappropriate land cover composition within them (Tables 3, 4, 5 and 6).

Table 3. Metrics of corridors 1-3 in 1990.

\begin{tabular}{|c|c|c|c|c|c|c|c|}
\hline Metrics & $\begin{array}{l}\text { Low- } \\
\text { Dense }\end{array}$ & $\begin{array}{l}\text { Semi- } \\
\text { Dense }\end{array}$ & $\begin{array}{l}\text { High- } \\
\text { Dense }\end{array}$ & Pasture & Agriculture & $\begin{array}{l}\text { Man- } \\
\text { made }\end{array}$ & Bare \\
\hline Area (ha) & 22.4 & 191 & 69 & 3.1 & 0.09 & 7 & - \\
\hline $\begin{array}{l}\text { Number } \\
\text { of patches }\end{array}$ & 231 & 97 & 183 & 21 & 3 & 65 & - \\
\hline $\begin{array}{l}\text { Mean of } \\
\text { patches } \\
\text { (ha) }\end{array}$ & 0.1 & 2 & 0.38 & 0.1 & 0.03 & 0.1 & - \\
\hline $\begin{array}{l}\text { Edge } \\
\text { density } \\
\text { (m/ha) }\end{array}$ & 104 & 203 & 178 & 13 & 0.9 & 31 & - \\
\hline $\begin{array}{l}\text { Total } \\
\text { edge }(\mathrm{m})\end{array}$ & 20379 & 88656 & 52107 & 3865 & 251 & 9198 & - \\
\hline
\end{tabular}


Table 4. Metrics of corridors 1-3 in 2015.

\begin{tabular}{lccccccc}
\hline Metrics & $\begin{array}{c}\text { Low- } \\
\text { Dense }\end{array}$ & $\begin{array}{c}\text { Semi- } \\
\text { Dense }\end{array}$ & $\begin{array}{c}\text { High- } \\
\text { Dense }\end{array}$ & Pasture & Agriculture & $\begin{array}{c}\text { Man- } \\
\text { made }\end{array}$ & Bare \\
\hline Area (ha) & 68.3 & 149 & 51 & 2.1 & - & 7.3 & - \\
\hline $\begin{array}{l}\text { Number of } \\
\text { patches }\end{array}$ & 520 & 291 & 237 & 32 & - & 121 & - \\
\hline $\begin{array}{l}\text { Mean of } \\
\text { patches (ha) }\end{array}$ & 0.1 & 0.5 & 0.2 & 0.1 & - & 0.1 & - \\
\hline $\begin{array}{l}\text { Edge } \\
\text { density }\end{array}$ & 266 & 352 & 352 & 12 & - & 38 & - \\
(m/ha) & 73869 & 97968 & 49970 & 3253 & - & 10601 & - \\
\hline $\begin{array}{l}\text { Total edge } \\
(\mathrm{m})\end{array}$ & & & & & &
\end{tabular}

Table 5. Metrics of corridors 1-4 in 1990.

\begin{tabular}{lccccccc}
\hline Metrics & $\begin{array}{c}\text { Low- } \\
\text { Dense }\end{array}$ & $\begin{array}{c}\text { Semi- } \\
\text { Dense }\end{array}$ & $\begin{array}{c}\text { High- } \\
\text { Dense }\end{array}$ & Pasture & Agriculture & $\begin{array}{c}\text { Man- } \\
\text { made }\end{array}$ & Bare \\
\hline Area (ha) & 24 & 165 & 91 & $4 / 2$ & - & 1.6 & - \\
\hline $\begin{array}{l}\text { Number of } \\
\text { patches }\end{array}$ & 222 & 100 & 134 & 33 & - & 24 & - \\
\hline $\begin{array}{l}\text { Mean of } \\
\text { patches (ha) }\end{array}$ & 0.1 & 1.6 & 0.7 & 0.1 & - & 0.1 & - \\
\hline $\begin{array}{l}\text { Edge } \\
\text { density } \\
\text { (m/ha) }\end{array}$ & 107 & 252 & 367 & 16 & - & 9 & - \\
\hline $\begin{array}{l}\text { Total } \\
\text { edge(m) }\end{array}$ & 30682 & 72071 & 100991 & 4621 & - & 2507 & - \\
\hline
\end{tabular}

Table 6. Metrics of corridors 1-4 in 2015.

\begin{tabular}{lccccccc}
\hline Metrics & $\begin{array}{c}\text { Low- } \\
\text { Dense }\end{array}$ & $\begin{array}{c}\text { Semi- } \\
\text { Dense }\end{array}$ & $\begin{array}{l}\text { High- } \\
\text { Dense }\end{array}$ & Pasture & Agriculture & $\begin{array}{c}\text { Man- } \\
\text { made }\end{array}$ & Bare \\
\hline Area (ha) & 58 & 138 & 67 & 4.9 & - & - & 7.3 \\
\hline $\begin{array}{l}\text { Number of } \\
\text { patches }\end{array}$ & 487 & 309 & 221 & 37 & - & - & 174 \\
\hline $\begin{array}{l}\text { Mean of } \\
\text { patches (ha) }\end{array}$ & 0.1 & 0.4 & 0.3 & 0.1 & - & - & 0.04 \\
\hline $\begin{array}{l}\text { Edge } \\
\text { density } \\
\text { (m) }\end{array}$ & 271 & 367 & 191 & 22 & - & - & 52 \\
\hline $\begin{array}{l}\text { Total edge } \\
\text { (m) }\end{array}$ & 74457 & 100991 & 52627 & 5966 & - & - & 14569 \\
\hline
\end{tabular}

As a result, in all corridors, the relative share of semi-dense and dense forest cover were reduced and the share of other land cover was added. Moreover, the quality of corridors indicated a decline in their integrity. As a result, the metrics of number of patches, edges density and total edges increased and the metric of average patch decreased. All these showed habitat fragmentation and loss of connectivity. 
Habitat change in the region in general and for Caspian red deer in particular, indicated that the mere establishment of a region as a protected area, coupled with developing and determining rules and regulations for its control, is not a comprehensive strategy for the protection of biodiversity and habitats, but also operational requirements and more importantly, the monitoring of changes in these areas are very important. The results of the present study showed that the area is severely degraded and as such, the major approach towards resolving this issue should be based on reconstruction and restoration of the area through the restoration of indoor arenas and finding possible natural opportunities in the outside for the development of the protected area by natural corridors. This approach requires a change in traditional methods and the use of new methods based on maintenance of land integrity and development of habitat networks. The findings of this study are in line with the results of Feest et al. (2010) who reported that landscape metrics are good predictors of the structural and functional integrity of habitats.

Acknowledgements. We appreciate of cooperation of Lisar Protected Area staff particularly game guards.

\section{REFERENCES}

[1] Aguilar, R., Quesada, M., Ashworth, L., Herrerias-Diego, Y., Lobo, J. (2008): Gen consequences of habitat fragmentation in plant populations: Susceptible signal in plant traits and methodological approaches. - Molecular Ecology 17: 5177-5188.

[2] Andelman, S.J., Willing, M.R. (2003): Present patterns and future prospects for biodiversity in the Western Hemisphere. - Ecology Letter 6: 818-824.

[3] Andrén H. (1994): Effects of habitat fragmentation on birds in landscapes with different proportions of suitable habitat: A review. - Oikos 71:355-366.

[4] Auffret,A.G ., Plue, J., Cousins ,S. A. O. (2015): The spatial and temporal components of functional connectivity in fragmented landscape. - AMBIO 44:51-59.

[5] Balmford, A., Bruner,A., Cooper, P.(2002):Ecology-Economic reasons for conserving wild nature.- Science 297: 950-953.

[6] Beier, P., Majka, D.R. ,Newell, S.L. (2009): Uncertainty analysis of least-cost modeling for designing wildlife linkages- Ecological Applications 19: 2067- 2077.

[7] Bruijnzeel, L.A. (2004): Hydrological functions of tropical forests: Not seeing the soil for the trees? - Agriculture, Ecosystems \& Environment 104: 185-228.

[8] Ellis, E.C., Goldewijk, K.K., Siebert, S., Lightman, D., Ramankutty, R.N. (2010): Anthropogenic transformation of the biomes, 1700 to 2000. - Global Ecology and Biogeography 19:589-606.

[9] Ewers RM ., Didham RK. (2005): Confounding factors in the detection of species responses to habitat fragmentation. - Biological Reviews 81:117-142.

[10] Fahrig L. (2003): Effects of habitat fragmentation on biodiversity. - Annual Review of Ecology, Evolution, and Systematics 34:487-515.

[11] Feest,A., Aldred,T.D ., Jedamzik, K. (2010): Biodiversity quality: A paradigm for biodiversity.-Ecological Indicators 10:1077-1082.

[12] Fischer, J., Lindenmayer, D.B. (2007): Landscape modification and habitat fragmentation: A synthesis. - Global Ecology and Biogeography 16:265-280.

[13] Gholipour, M. (2012): Determination of protection class of Caspian red deer under the conditions of uncertainty in the north of Iran. MSc thesis. Gorgan University of Agricultural and Natural Resource Sciences. 
[14] Guilan Department of Environment. (2005): Master Plan of Lisar Protected Area, Section (6): Climate and weather.

[15] Guilan Department of Environment. (2005): Master Plan of Lisar Protected Area, Section (2): Geology and geomorphology.

[16] Guilan Department of Environment. (2005): Master Plan of Lisar Protected Area, Section (10): Vegetation.

[17] Guilan Department of Environment. (2005): Master Plan of Lisar Protected Area, Section (10):Wildlife.

[18] Hanski, I. (2011): Habitat loss, the dynamics of biodiversity, and a perspective on conservation. -AMBIO 40:248-255.

[19] Kiabi, B.h., Gaemi, A.,Jahanshahi, M., Sassania (2004): Population status, biology and ecology of the Maral, Cervus elaphus maral, in Golestan National Park, Iran.Zoology in the Middle East 33:125-138.

[20] Krosby, M., Tewksbury, J., Haddad, N.M., Hoekstra, J. (2010): Ecological connectivity for a changing climate. - Conservation Biology 24:1686-1689.

[21] Laurance, W.F., Useche, D.C. (2009): Environmental synergisms and extinctions of tropical species. - Conservation Biology 23: 1427-1437.

[22] Lienert, J. (2004): Habitat fragmentation effects on fitness of plant populations-A review. -Journal for Nature Conservation 12:53-72.

[23] Lopoukhine,N.,Crawhall, N., Dudley, P., Faggis, C., Karibouhoye, D, Laffoley, J: Protected Areas: providing natural solutions to $21 \mathrm{st}$ century challenges, A.P.I.EN.S[online].5.2.(2012). Online Since 10 August 2012, connection on 26 December 2015. URL: http://sapiens.revues.og/125.

[24] Majka, D., Jenness, J., Beier, P. (2007): Corridor Designer: ArcGIS tools for designing andevaluating corridors. Available at http://corridordesign.org.

[25] Parvian, N. (2012): Impact assessment of changes in land use and vegetation on habitat of Caspian red deer, Gorgan and Kordkoi- Iran-MSc thesis. Gorgan University of Agricultural and Natural Resource Sciences.

[26] Pflüger, F.J., Balkenhol, N. (2014): A plea for simultaneously considering matrix quality and local environmental conditions when analyzing landscape impacts on effective dispersal. -Molecular Ecology 23:2146-2156.

[27] Potts, S.G., Biesmeijer, J.C., Kremen C. (2010): Global pollinator declines: Trends, impacts and drivers. -Trends in Ecology and Evolution 25: 345-353.

[28] Rempel, R.S., Kaukinen, D ., Carr A.P. (2012): Patch Analyst and Patch Grid. Ontario Ministry of Natural Resources. Centre for Northern Forest Ecosystem Research, Thunder Bay, Ontario.

[29] Ricketts, T., Regetz, J.H., Steffan-Dewenter, I. ( 2008): Landscape effects on crop pollination services: Are there general patterns?- Ecology Letters 11: 499-515.

[30] Sawyer, S. C., Epps, C .W., Brashares, J. S. (2011): Placing linkages among fragmented habitats: do least-cost models reflect how animals use landscapes? Applied Ecology 48: 668-678.

[31] Taylor, P.D., Fahrig, L., Merriam, G. (1993): Connectivity is a vital element of landscape structure.- Oikos 68: 571-573.

[32] Trainor, A.M., Walters, J.R., Morris, W.F., Sexton, J., Moody, A. (2013): Empirical estimation of dispersal resistance surfaces: a case study with red-cockaded woodpeckers. - Landscape Ecology 28:755-767.

[33] Waldhardt, R. (2003): Biodiversity and landscape-summary, conclusions and perspectives. -Agriculture Ecosystem and Environment 98:305-309.

[34] Wiens, J.A. (2009): Landscape ecology as a foundation for sustainable conservation. Landscape ecology 24:1053-1065. 
[35] Zebardast, L. (2011): Analyzing the possibility of utilizing landscape ecology to reduce uncertainty in environmental impact assessment. Case study: Road crossing Golestan National Park. Ph.D Dissertation. University of Tehran.

[36] Zeller, K.A., McGarigal, K., Whiteley, A.R. (2012): Estimating landscape resistance to movement: a review. - Landscape Ecology 27:777-797. 